\title{
ÉLŐNYELV
}

\section{Balaton vidéki fiatalok tájszókészletéről egy kérdőíves vizsgálat tükrében*}

1. Bevezetés. A dialektológia képviselői körében általánosan elfogadott tény, hogy a nyelvjárások kutatása korántsem csupán archaizálódó jelenségeket foglal magába, hiszen a területi variabilitás olyan természetes velejárója a nyelvhasználatnak, amelynek strukturális és pragmatikai szempontból egyaránt megfigyelhető változásait a dimenzionális nyelvszemléletet követve a beszélöközösség mai, fiatalabb tagjai körében is érdemes vizsgálni (a kérdéskör elméletéröl 1. JUHÁSZ 2002; HEGEDÜS 2005; KISS 2013, 2017; újabb kutatási eredményekhez a teljesség igénye nélkül vö. pl. a Dialektológiai Szimpozion legutóbbi köteteinek - GUTTMANN-MOLNÁR 2007; CZETTER et al. 2016 - számos tanulmányát, 1. még pl. HAJBA 2012; KONTRA et al. 2016; BODÓ-FAZAKAS 2018). „Metaforával élve: a nyelvjárási változat nem skanzen ebben a vizsgálati modellben, hanem élö, lakott falu” (NÉMETH 2006: 255). E tény azonban a nyelvtudomány más területeinek a müvelöi számára sem teljes mértékben közismert (vö. KISS 2015; PÉNTEK 2015; de 1. pl. HELTAINÉ NAGY 2004), a társadalom többi tagja előtt pedig még kevésbé. A beszélőközösség jelentős hányadának erre utaló megnyilvánulásait spontán módon talált adatok sokasága jelzi, a megfigyeléseket pedig objektív kutatási eredmények is igazolják, amelyek közül néhányról a következökben szólok röviden.

Egy, az ország egyetemistái körében 2017 őszén végzett felmérés (részletesen 1. PARAPATICS 2020a: 16-22) szerint még a frissen érettségizett fiatalok, a magyar társadalom leendő értelmiségi tagjai közül is sokan öntudatosan kijavítják a nyelvterület különböző tájairól érkezett társaikat, ha szerintük „,nem létező” szavakat, „hibás” nyelvtani formákat használnak „csúnya” kiejtéssel, és fordítva: ők is kaptak már lekicsinylő megjegyzéseket társaiktól, oktatóiktól és akár ismeretlenektől is otthonról hozott nyelvhasználatuk miatt. Bár elméletben sok adatközlő hangsúlyozta azt az adatgyüjtés idején érvényben lévő Nemzeti alaptanterv elvárásaival egybehangzóan (vö. pl. NAT 10666, 10673), hogy a nyelvi helyesség régiótól független, s hogy a sokféleség tiszteletben tartandó, mégis számos olyan nyelvi jelenséget soroltak fel számukra elviselhetetlen hibaként, amelyek háttere szintén a regionális változatosság. A vizsgálatban több mint 500 egyetemista vett részt.

Hasonló ambivalenciáról tanúskodnak egy pedagógusok véleményét felmérő kérdöíves vizsgálat eredményei (1. PARAPATICS 2020a: 63-75). A 2015 és 2018 között zajló kutatásban részt vevő 170 pedagógus mindegyike értékes, megőrzendő és ápolandó hagyományként tekint a dialektusokra, válaszaik tanúsága szerint a gyakorlatban viszont már irtani próbálják a regionalizmusokat a tanulók nyelvhasználatából azt gondolván: a nyelvjárási beszéd az idősebb, iskolázatlan, falusi emberek, továbbá a határon túli magyarok

*A tanulmány az EFOP 3.6.1-16-2016-00015 azonosítószámú „Pannon Egyetem átfogó intézményfejlesztése az intelligens szakosodás elősegítése érdekében” című projektje keretében készült.

DOI: 10.18349/MagyarNyelv.2020.3.337 
sajátja. Noha a témakör a kerettantervben (KT) és így a tankönyvekben is megjelenik, kevesen foglalkoznak vele a tanórán, mert a nyelvjárásokat archaizmusoknak tartják, amelyekkel a mindennapi életben úgysem találkoznak a tanulók (HUDSON 2004 figyelmeztet az anyanyelv szakos pedagógusok képzésének a hiányosságaira, a magyartanárok felkészítéséhez azonban 1. pl. GUTTMANN 1999; KISS 2000; MDial.; Cs. NAGY - N. CSÁSZI 2015; SZENTGYÖRGYI 2015). JÁNK ISTVÁN (2018) ügynökmódszer alkalmazásával közel 500 fös mintán igazolta, hogy a kérdésben mutatkozó hiányosságok nyelvi diszkriminációhoz vezetnek a pedagógiai értékelés folyamatában (a lingvicizmus jelenségéhez vö. még pl. KONTRA 2006). Mindezek tükrében nem meglepők az egyetemisták metanyelvi tájékozatlanságáról kapott adatok (kapcsolódó eredményekről 1. FODOR 2003; STRELI 2007; KISS 2009, 2010; BorOs 2010). Korábbi kutatásokon (pl. GUTTMANN 1995; PleTL 1997; KISS 1998) túl néhány újabb tanulmány is vizsgálja a nyelvjárási háttérből fakadó helyesírási hibák kérdését (pl. BODA 2011; PARAPATICS 2016a; HANICZKO 2017; KoÓs 2017), és az anyanyelvi tudatosság fejlesztésének a módszereit (pl. BODA 2011; PARAPATICS 2018 és 2020a; a kérdés nemzetközi szakirodalma meglehetősen bö, és néhány nyelvvel kapcsolatban nagy hagyományokkal bír, a teljesség igénye nélkül vö. pl. AMMON et al. 1978; LÖFFLER 1985; AMMON et al. 1989; HuSBY 2008; HONDA et al. 2010; VANGSNES et al. 2017).

2. Célkitúzés. A jelen tanulmányban bemutatott vizsgálat célja annak a feltételezésnek az igazolása, hogy A magyar nyelvjárások atlaszában (a továbbiakban: MNyA., Nagyatlasz) közölt tájszavak közül több a mai fiatalok mentális lexikonának is részét képezi, akár aktív, akár passzív formában. Hipotézisem, hogy a közép-dunántúli-kisalföldi nyelvjárási régió Balaton vidéki területén élö 14-18 éves fiatalok számos olyan tájszót ismernek és használnak ma is, amelyeket az 1949 és 1964 között gyüjtött adatokat feldolgozó Nagyatlasz a lakóhelyükhöz közeli vagy azzal megegyező kutatópontokon adatol. A vizsgálat közvetett célja, hogy a nagyszámú objektív nyelvi adat és az elemzésükkel kapott eredmények tényként cáfolják a nyelvjárások eltűnéséről szóló általános és felületes tévhitet. A tanulmány egyik névtelen lektora arra figyelmeztet, hogy e kérdések vizsgálata kevés tudományos hozadékkal jár amiatt, hogy a várható eredmények a szaktudományi kutatók körében magától értetődők. A dialektológusok számára valóban nem fér kétség a regionalizmusok élő voltához. Azonban fontosnak tartom, hogy a mindennapi tapasztalatokat megismételhető kutatási eredmények is alátámasszák, amelyeket tudományos hozadéknak tekintek. Emellett a vizsgálat közvetett hozadékának tartom, hogy az eredmények hivatkozási alapként szolgálhatnak olyan kérdésekben, mint például a dialektológia oktatásának létjogosultsága, szerepe a tanárképzésben (1. az előző pontban), továbbá a tudományterület megítélésével, intézményi hátterével, a dialektológiai kutatások szervezettségével és támogatásával kapcsolatos döntések terén (minderről részletesen 1. KISS 2015). „A nyelvjárásokról [már] néhány évtizeddel ezelőtt egyes nyelvészek is úgy beszéltek, mint távoli, már-már eltünő kuriózumokról” (PÉNTEK 2015: 17, idézi KISS 2015: 387), vagyis a tévhitek nem csak laikus körben keresendök.

3. Anyag és módszer. A vizsgálat alanyai egy Balaton-felvidéki kisváros, a kb. 15.000 föt számláló Tapolca egyetlen gimnáziumának tanulói voltak. Az adatgyüjtést személyesen végeztem 2018 novemberében, amelynek során a négy évfolyamos iskola összes - évfolyamonként két-két - osztályát felkerestem egy-egy tanóra erejéig. Így 
az adatgyüjtés napján éppen hiányzó tanulók kivételével az iskola teljes diáksága részt vett a kutatásban, pontosan 200 fö. Az adatgyüjtés két napon keresztül négy-négy egymást követő tanórán zajlott, így a különböző osztályba járó tanulóknak kevés lehetőségük nyílt a kutatás kérdéseinek a megvitatására.

Az intézmény tanulói közösségét megközelítőleg fele-fele arányban teszik ki a városban élő és a környékbeli falvakból - általában 10-15 kilométeres vonzáskörzetből, de esetenként akár 20-30 kilométerről is - naponta bejáró diákok. Noha a tanulók kollégiumi ellátást is igényelhetnének, ezzel a lehetőséggel egyikük sem élt sem az adatgyüjtés időpontjában, sem azt megelőzően. A gimnázium az országos rangsorban átlagos helyen szerepel az országos kompetenciamérés és a továbbtanulás eredményei alapján, az érettségi vizsga megkezdéséig a tanulók jelentős része szerez legalább középfokú komplex nyelvvizsgát legalább egy idegen nyelvböl.

Az adatközlők magas létszámára való tekintettel az adatgyüjtés módszere a papíralapú kérdöív volt, amelyet a tanulók önállóan töltöttek ki a felügyeletem alatt. A kitöltés átlagosan 35-45 percet vett igénybe, amelyet szóban elhangzó instrukciók előztek meg, illetve szükség esetén kísértek. A kérdöív a Nagyatlasz 88 tájszavára kérdezett rá a Tapolca környéki kutatópontokon (Diszel, Szentgál, Kapoles) jelölt adatok felhasználásával. A tájszavak kiválasztásának szempontjai a következők voltak: 1. Olyan szó legyen, amely nem hangtani vagy alaktani szinten hordoz regionális jegyet, hanem valódi, esetleg jelentésbeli tájszó. 2. Olyan szó legyen, amely a mai átlagos (vidéki) életformához is kötődik, így használata a gimnazista fiatalok körében is releváns lehet. Nem szerepeltek tehát a kérdőívben például a kocsikerék részei vagy a kenderfonás szavai, sem pedig a köznyelvben is használt szavak hangtani sajátosságait (pl. madár) vagy az alaktani variánsokat (pl. méhei, aludnék) kutató kérdések. Szerepeltek viszont állatokat (pl. kánya 'feketevarjú'), növényeket (pl. bicske 'csipkebogyó'), ma is használatos tárgyakat (pl. sámli 'kisszék') ételeket (barátfüle 'derelye'), külső és belső emberi tulajdonságokat (pl. kerbenézö 'kancsal', zsugori 'fukar'), időjárási jelenségeket (pl. kiviccsanik 'kitisztul az ég'), cselekvéseket (pl. májog 'nyávog', nyökög 'akadozva beszél') stb. jelölő tájszavak.

A tanulók feladata az volt, hogy jelöljék, 1. használják-e a megadott tájszót, 2. használják-e szüleik vagy nagyszüleik, 3. adják meg, írják körül a szó jelentését, 4. ha használnak, írjanak rá szinonimát. A kérdések szerepe az volt, hogy kiderüljön, van-e olyan szó, amelyet ők ugyan nem használnak, esetleg nem is ismernek, de hallották már otthon, illetve van-e olyan, amelynek tudják a jelentését, de nem használják. A jelentés megadására azért volt szükség, hogy ellenőrizhessem, valóban tudják-e a válaszadók annak a szónak az értelmét, amelyet önbevallásuk szerint használnak. Így kiküszöbölhetővé válik annak a problémája, ha az adatközlők csupán meg szeretnének felelni a kutatónak tulajdonított elvárásnak, miszerint az az előnyös, ha minél több tájszót jelölnek használatosként. Végül a rokon értelmü szóra kérdezve kiderülhetett, ha az adatközlők nem is ismernek más, köznyelvi változatot az adott tájszó esetén, illetve lehetőséget adott nekik arra, hogy ha nem tudták megfelelően körülírni a tájszó fogalmát, akkor egy szinonimával helyettesíthessék azt.

Noha a tájszavak ismeretét hagyományosan e módszer fordítottjával, szóban szokásos felmérni, amely során a körülírás hangzik el a kérdezőtől, a tájszó pedig az adatközlötől, használatát pedig további módszerekkel, ezeket jelen kutatásban nem alkalmazhattam, viszont több tényező segített csökkenteni az ezzel járó kockázatot. 
A szokásos módszer alkalmazásának legfőbb gátja az emberi tényező volt: ahhoz, hogy közel egyidőben gyüjthessek anyagot egy relatíve kis és zárt közösség minden tagjától, anélkül, hogy a később kérdezett adatközlök felkészülhessenek a válaszokkal (ezzel torzítva az eredményeket), írásban kitölthető kérdőívre volt szükség. A megkérdezett korosztály tagjai körében az adatgyüjtés helyszínén szerzett tízéves közoktatási tapasztalatom alapján feltételeztem, hogy jóval kevesebb tájszó ismeretéről tudtak volna beszámolni a tanulók akkor, ha nekik kell megadniuk azokat úgy, hogy nem segíthetem a válaszadást további szóbeli rávezetéssel. Jellemző képet nyújt a helyzetről néhány adatközlő megjegyzése a kérdőív végén (a megjegyzéseket a helyesírási hibák javítása nélkül közlöm): „Nagyon tetszett a kérdőív, mert jó volt néhány szót látni amit gyakran nem használok” (11. osztályos lány); „Van pár szó ezek között amit talán egyszer hallottam és már nem tudom hogy hol és a jelentését sem tudom” (10. osztályos fiú); „Érdekes, hogy itt élek és azt gondoltam sok mindent ismerek a nagyszüleim által, de nem. Jó volt találkozni ezekkel a szavakkal” (10. osztályos lány).

Az így megszerkesztett és írásban kitöltetett kérdőív módszerének legfőbb kockázata az volt, hogy az adatközlök több tájszót jelölnek ismertnek és használatosnak, mint amennyi valós tudásukat és nyelvhasználatukat jellemzi. Ezt tehát a jelentés megadását kérő rovat tette ellenőrizhetővé. Ahogyan várható volt, a tanulók valóban számos olyan szót is használtnak jelöltek, amelyeket aztán tévesen definiáltak, ezekben az esetekben nem vettem figyelembe a jelölést.

A téves próbálkozások egyik típusa az alaki hasonlóság volt, például a 'csipkebogyó' jelentésü bicské-röl sokan a bicskára asszociáltak, a 'vakond' jelentésü pucok-ról a pocokra, a zsugori 'fukar' szóról a kis méretre vagy éppen a zsugorfóliás, hat darabos ásványvízre (vö. zsugorviz), a hüss 'hüvös' szóról az állatterelésre (vö. hess). Így lett a 'pocsolya, tócsa' jelentésű pocsétá-ból és a 'kavics' jelentésű gübics-ből „,madár” (vö. nádiposzáta, gébics), a körmöz-böl ,gyorsan ír, másol” (vö. körmöl) vagy „régi nevelési módszer” (vö. körmöst ad) a 'karmol' helyett, a pök-ből ,pók”, a pörc-ből pedig ,perc” vagy ,porc” a 'köp' és a 'szalonnából kisütött zsír' helyett. Az elsemved 'elzsibbad' több helyen ,elszenved” magyarázatot kapott, a nyökög (vö. nyög) és a höbög 'akadozva beszél' „nyögdécsel”, illetve „valami nem tetszik neki” (vö. hőbörög) jelentést.

A tanulók másik módszere egyfajta etimologizálás volt, például bélpoklos 'aki mindig enni kíván': „,akkor mondják, ha valami baj van a hasaddal” vagy „,nehezen megemészthető étel, mely megüli a gyomrot” vagy ,,aki sokat eszik és sokszor alattomosan is”; hidas 'ól': „szegény ember (híd alatt él)” vagy „hídnál dolgozó”, „hidat építo”; kitisztul 'kiderül (az ég)': „kijózanodik”; pesszeg 'sziszeg (lúd)': „elhallgattat” (vö. pisszeg); ripacsos 'sebhelyes arcú': ,rossz színész” vagy „hangoskodó”, „feltünősködik” (vö. ripacs); szeme bogara 'pupilla': „,valakinek a legfontosabb személye”, „kedveskedés” (vö. szeme fénye); tutyi 'cipő': „gyenge akaratú ember”, „,ilyen nyápic”, „anyámasszony katonája” (vö. tutyimutyi); uritök 'sütőtök': „nagyképü”, ,sokat képzel magáról” vagy „,elegáns” vagy ,akit elkényeztetnek”; viselös 'állapotos’: „,sokat hordott ruha” (vö. viseletes) vagy „mutatós, viselni való” vagy „ad magára”.

Végül számos olyan megoldás is született, ahol az adatközlők csupán a tájszó egy másik, köznyelvi vagy szleng jelentését ismerték, így használatának jelöltsége is arra vonatkozott, például birka 'juh': ,,amikor valaki hülye”, „,valaki béna”; csuha 'kukorica levele': ,papi ruha”; fosztás 'kukorica levele': „rablás”; hont 'göröngy': „haza régiesen”; 
kürt 'kályhacső': „fúvós hangszer”; tusa 'kukoricacső': „,vívásban használatos szó”; szelence 'orgona': „kis doboz”.

Az ilyen eseteket tehát ugyanúgy nemleges válasznak vettem az adatközlök nyelvhasználatát illetően, mint a teljesen téves (l. fent), a hiányos (pl. kövesztett szalonna: ,a szalonna egy fajtája”, ,étel”) vagy a magyarázat nélkül hagyott szavak esetén. Megjegyzendő, hogy az adatközlök válasza több esetben is arra utalt, hogy ismerik a szót, tudják a jelentését, mégsem tudják elmagyarázni, például: „gyürke: nem jut eszembe, de ismerős”.

Az adatgyüjtés során a tanulók engedélyt kaptak arra, hogy verbális definiálás helyett lerajzolhassák az adott tájszót, ezzel általában azokban az esetekben éltek, amikor nem is tudtak köznyelvi szinonimát az adott szóra (pl. a kukorica haja, sámli), és könynyebb volt számukra így, mint körülírni. Egy tanulónak az angol nyelv segített a jelentés megadásában, aki a birka szóra a „sheep” magyarázatot adta. A definíciók olykor az adatközlők saját, mai tapasztalatait és nyelvhasználatát tükrözték, például tutol 'hosszan elnyújtva üvölt’: „kutyák ezt csinálják, ha szirénát hallanak” vagy „amit a huskyk adnak ki”; nyökög: ,én versmondáskor”; nagyevő „,sokat eszik (húgom)” vagy „nagy adag kaját eszik”. Ezek megfelelő magyarázatnak számítottak a kérdőívek kiértékelésében.

Az alkalmazott anyaggyüjtési módszer további kockázatait a kutatói jelenlét volt hivatott csökkenteni. Mind a nyolc osztályban személyesen, az osztályban tanító pedagógusok jelenléte nélkül töltettem ki a kérdöívet. Így azonnal és könnyen tisztázhattuk a félreértésekre okot adó tényezőket, eloszlathattam a formális vizsgaszituáció hangulatát, miközben felügyelhettem, hogy az adatközlök valóban önállóan töltsék ki a kérdőívet.

4. Eredmények. Miként az várható is volt, nem minden adatközlö ( $\mathrm{n}=200$ fö) tudta a jelentését a kérdőívben megkérdezett összes tájszónak (88 db), és nem mindenki használja azokat. Az eredmények tárgyalása során a „használ” igét alkalmazom, noha a tanulók erre vonatkozó önbevallása további vizsgálat híján nem biztos, hogy teljesen megbízható adatokat ad. A szóhasználat egyik oka, hogy az adatközlők a „használat”-ra vonatkozóan adták meg válaszaikat, és meggyőződésem, hogy a személyes kapcsolat és jelenlét révén eloszlathattam a kutatói elvárásoknak való megfelelés igényét, akár a használat letagadását, akár a valóságosnál több szó használatának jelölését illetően. A szóhasználat másik oka, hogy ezzel különböztethető meg, amikor valaki csupán ismeri, de nem használja az adott tájszót. Jelen dolgozat nem részletezi az utóbbi típusba tartozó adatokat, csupán említést tesz néhány ilyen esetről, ezzel felvázolva egy újabb tanulmány célkitüzését. Végezetül, miként az előző pont hangsúlyozta: a tájszó használatára vonatkozó jelöléseket csak abban az esetben vettem érvényesnek, ha a jelentés megadása, körülírása elfogadható volt. Köszönöm a tanulmány egyik lektorának, hogy felhívta figyelmemet a szóhasználattal kapcsolatos problémára.

A tájszavakra érkezett válaszokat az alábbi csoportokra bontva közlöm, esetenként ábrával is szemléltetve: 1. Senki sem használja (nem használja, vagy nem adott rá magyarázatot, vagy téveset adott), azaz a tájszó egyetlen értékelhető jelölést sem kapott. 2. Kevesebb, mint az adatközlök 10\%-a használja ( $<20$ fö). 3. Az adatközlök legalább 10\%-a, de nem több, mint 50\%-a használja (20 fö $<\mathrm{n}<100$ fö). 4. Az adatközlők több, mint fele használja ( $\mathrm{n}>100$ fö).

Az 1. csoport tagjai közé 14 tájszó került. Egyetlen tanuló sem használja állítása szerint a következő szavakat: börkéshurka 'disznósajt', elsemved 'elzsibbad', fosztás 
'kukorica levele', fölöstököm 'reggeli', hidas 'ól', himpér 'málna', kerbenézö 'kancsal', kusztora 'fanyelü bicska', neveletlenujj 'gyürüsujj', péterke 'katicabogár', széktya 'tojássárgája', szelence 'orgona', valamint az ipam 'após' és a napam 'anyós'. Jellemző példa, hogy bár utóbbi két tájszóra egyetlen megfelelő jelentés sem érkezett, a tanulók nagy része hallott már róla, és a kérdőív végi „Egyéb megjegyzések” sorában a következő adalék érkezett: „Ipadnak, napadnak, három papnak, hat kappannak hány lába van?”. Ez az adatközlö (12. osztályos lány) 'nagypapa'-ként és 'nagymama'-ként értelmezte e két tájszót. Noha használtnak nem jelölte, egy-egy adatközlő helyes jelentésben ismeri a börkéshurka szót, a többit viszont még csak nem is ismerik a válaszok tanúsága szerint.

A 2. csoportba 36 tájszó került az adatok alapján. Kevesen használják például az általában más, nem tájnyelvi jelentéssel magyarázott tusa és csuta szavakat, vagy a téves próbálkozásoknál is említett buborcsék, hont, höbög, körmöz, kürt, pesszeg, pocséta, pök, pörc, pucok, ripacsos, viselös tájszavakat. Csupán néhány adatközlő használja és ismeri például a ciha, dönög, kézfogó, kiviccsanik, pillogat, hamvaskánya szavakat.

A 3. csoportban 26 tájszót használ legalább 20 és legfeljebb 100 adatközlő saját bevallása szerint. Ezen belül kevesebb jelölés és elfogadható magyarázat ( $30 \%$ alatti) érkezett a bangócs, bicske, csettent, csuha, disznóölö, hüss, köpcös, kövesztett szalonna, kukorica feje, lehöl/lehincöl, macskaméz, megborjazik/megborgyazik, ókula, sámedli, szembogár/szeme bogara, turcsi, tutyi szavakra (17 db), és több a bélpoklos (38,5\%), fukar (49,5\%), gyürke (33,5\%), kukorica haja (42,5\%), májog (30\%), nagyevö (40\%), nyökög (39,5\%), szemetel (eső) (43\%), tutol (39,5\%) (9 db) szavakra.

A 4. csoportba a következő 12 szó került: barátfüle (54\%), birka (86,5\%), csibe (89,5\%), csöpörög (85\%), kaccsa (szőlőnek) (54\%), kánya (61\%), kitisztul (ég) (62,5\%), okádik (69\%), réce $(60,5 \%)$, sámli $(71,5 \%)$, vánkos (52\%), zsugori (53,5\%). Várható volt, hogy a legismertebb szavak a birka és a csibe lesznek, míg a csöpörög jelentése könnyen ki is következtethetö. A személyes kitöltetés, a szóban többször hangsúlyozott instrukciók és az adatközlők további válaszai alapján (hiába tudták egy szó jelentését, nem mindig jelölték használatosnak) azonban feltételezem, hogy nem csupán a kikövetkeztetés állt a beszámítható válaszok mögött.

A 2., 3. és 4. csoport több szaváról egyaránt elmondható, hogy többen ismerik, mint ahány főnek az aktív szókincsét képezi. Néhány adatközlő a használat elutasítása mellett helyesen adta meg a jelentését például a buborcsék, csemcseg, gübics/gibics, kézfogó, kiviccsanik, pocséta, pök, pucok, ripacsos, zömöcskös szavaknak, amelyek a használat szempontjából mind a 2. csoportba tartoznak.

A kapott adatok megbízhatóságát igazolja az is, hogy az eredmények közel egységes képet mutatnak osztályonként. A kevéssé ismert és használt szavak más osztályokban sem elterjedtebbek, a közismert szavak mindegyik évfolyamon használatosak. A tanulók próbálkozásai a jelentések megadásához és nehézségeik a körülírás során szintén hasonló jellegüek voltak, és nagyjából ugyanazokat a szavakat érintették. Az életkortól független hasonlóságokat az 1. táblázat és az 1. ábra példázza. Az 1. ábrán a könnyebb viszonyítás érdekében minden szónál középen áll az összesített eredmények sávja, amelyet a legsötétebb szín jelöl. 


\section{1. táblázat}

Az egyes évfolyamokon kapott eredmények közötti hasonlóság néhány példával szemléltetve $(n=200)$

\begin{tabular}{|c|c|c|c|c|c|c|c|c|}
\hline \multirow[t]{2}{*}{ Tájszó } & \multicolumn{2}{|c|}{$\begin{array}{l}\text { 9. évfolyam } \\
(n=53)\end{array}$} & \multicolumn{2}{|c|}{$\begin{array}{l}\text { 10. évfolyam } \\
(n=62)\end{array}$} & \multicolumn{2}{|c|}{$\begin{array}{l}\text { 11. évfolyam } \\
(n=48)\end{array}$} & \multicolumn{2}{|c|}{$\begin{array}{l}\text { 12. évfolyam } \\
(n=37)\end{array}$} \\
\hline & fö & $\%$ & fö & $\%$ & fö & $\%$ & fö & $\%$ \\
\hline barátfüle & 23 & 43,4 & 35 & 56,5 & 27 & 56,3 & 23 & 62,1 \\
\hline csettent & 10 & 18,9 & 11 & 17,8 & 5 & 10,4 & 6 & 16,2 \\
\hline fukar & 26 & 49 & 29 & 46,8 & 22 & 48,9 & 22 & 59,5 \\
\hline gyürke & 14 & 26,4 & 18 & 29 & 15 & 31,3 & 20 & 54 \\
\hline hont & 0 & 0 & 2 & 3,2 & 0 & 0 & 0 & 0 \\
\hline kaccsa (szölönek) & 23 & 43,4 & 30 & 48,4 & 25 & 52 & 30 & 81 \\
\hline kánya & 37 & 69,9 & 39 & 62,9 & 26 & 54,2 & 20 & 54 \\
\hline macskaméz & 6 & 11,3 & 16 & 25,8 & 7 & 14,6 & 8 & 21,6 \\
\hline szijács & 1 & 1,9 & 1 & 1,6 & 1 & 2 & 0 & 0 \\
\hline zsurmol & 5 & 9,4 & 5 & 8 & 2 & 4,2 & 4 & 10,8 \\
\hline
\end{tabular}

\section{1. ábra}

Az egyes évfolyamokon kapott százalékos eredmények közötti hasonlóság néhány további példával szemléltetve $(\mathrm{n}=200)$

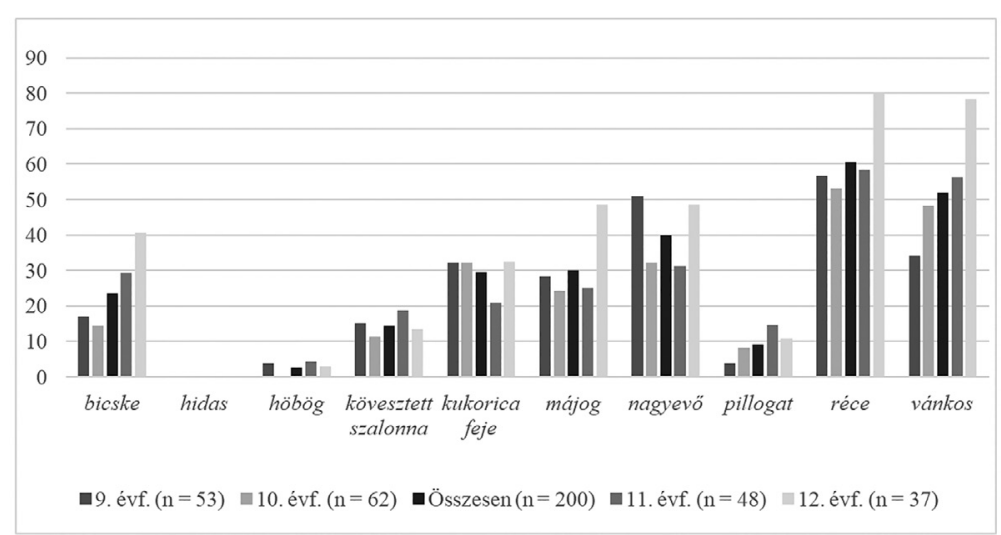

Látható, hogy bár a négy kategória szempontjából nincsenek jelentős eltérések évfolyamonként, a legidősebb, 12. osztályos tanulók válaszai olykor kiugró eredményt mutatnak a fiatalabb tanulókéhoz képest (vö. pl. gyürke, májog, kaccsa, réce, vánkos), általában a tájszó ismertsége és használata javára. Feltételezésem szerint ennek két oka lehet: 1. A 12. évfolyamos tanulók közül jóval kevesebben töltötték ki a kérdőívet (37 fö), mert a hivatalos osztálylétszámok is jóval alacsonyabbak más évfolyamokéhoz képest, így 
a kevesebb adat kiugróbb százalékos eredményekhez vezet (pl. ebből az évfolyamból egy fó adata már 2,7\%-ot jelent, míg a legnagyobb létszámú, 62 fös 10. évfolyamon ugyanez csupán 1,6\%-ot). 2. A végzős tanulók nyelvi tudata és szókincse valamelyest fejlettebb lehet fiatalabb társaikénál (hiszen elméletben ez az iskolai anyanyelvi nevelés egyik legfőbb feladata, vö. a kézirat leadásakor hatályos NAT-ot), így tudatosabbak lehettek a nyelvhasználatukat vizsgáló kérdőív kitöltésében, és könnyebben magyarázták meg a tájszavak jelentéseit is.

Fontos adalék, hogy a tanulók több ízben további nyelvjárási adatokat közöltek tudattalanul is a kérdezett tájszavak magyarázata során, illetve a kérdőív végén az „Egyéb megjegyzések" kérdésre válaszolva, amelyet nem volt kötelező kitölteniük. Ezek az adatok szintén nagy jelentőséggel bírnak a fiatalok regionális nyelvhasználatának, a régió hangtani és alaktani sajátosságainak (vö. JUHÁsz 2001) a vizsgálatában is: „,kaccsa (szőlőnek): a szőlő amivel kapcsolódik a levélhez és a t ü k é h e z ”; „hüss: h ü v ös ”; ,sanda: sanda g y a n u m ”; „kürt: fu j ó hangszer” (felső nyelvállású magánhangzók rövidülése); „kukorica haja: kukorica csúcsán lévő s z á 11 a k”; „kaccsa (szőlőnek): a s z ő 11 ő e v é s után marad” (intervokalikus nyújtás); „sámli: babák nyakába a k a s s z á k”; barátfüle: k ö z e p é b e lekvár van" (a kiemelések tölem: P. A.). A fogalommeghatározások között olykor további tájszó is megjelent: a disznóölö-t néhányan a böllér vagy a hentes szavakkal magyarázták, a szemetel időjárási jelenséget a szemerkél szóval, a tutol szóra pedig többször a vonyit érkezett válaszként (vö. még MNyA. és ÚMTsz.). Egyéb megjegyzésként többen felsoroltak további tájszavakat is: „rekamé = kihúzható kanapé, pirhanyagos = pirosodik a cseresznye”, „,hangya - hangyál, spájz - éléskamra”; „kaska - kosár”; „Mindig össze vagyok zavarodva, amikor a nagymamám beszél: a kamrára »spájzot« mond, a fakanapéra pedig azt, hogy »hokedli«" (11. osztályos lány). Valaki példák említése nélkül számolt be arról, hogy „Volt már olyan, hogy említették, hogy parasztosan beszélek” (11. osztályos lány). Végül néhány adalék a nyelvi attitüdök kérdésköréhez: „A nyírségben gyakorta használt a »Jösztök nálunk?«, ami elvileg itt értelmetlen” (11. osztályos lány); „Kiskoromban nyaraim jelentős részét nagyszüleimnél töltöttem az alföldön, ahol sok szóra érdekesen néztem” (11. osztályos lány); „Idegesít, ha valaki a faragóra azt mondja, hogy hegyező" (10. osztályos lány).

A kutatást ugyanebben az intézményben 2014 tavaszán is elvégeztem. Akkor az iskola 112 tanulójával, mind a négy évfolyam egy-egy osztályában töltettem ki ugyanezt a kérdőívet (a részletes eredményekhez 1. PARAPATICS 2016b). Összevetve az akkori kutatás adatait a frissebbével közel azonos arányokat láthatunk. A 2014. év gimnazistái körében végzett felmérés a legtöbb esetben minimális eltérésekkel ugyanazokat az eredményeket hozta, mint a jelenlegi vizsgálat, a százalékos adatok alapján nagyjából ugyanazok a tájszavak sorolhatók egy-egy adott kategóriába a négy közül. (A 2014-es adatok feldolgozása során szintén közel azonos eredmények születtek az egyes osztályokban.) Ezt a 2. táblázat és az 2. ábra szemlélteti. A 2. táblázat öt-öt példát mutat be a 4., legáltalánosabban használt tájszavak és a 2., alig használt tájszavak csoportjából. A százalékos eredmények jól mutatják, hogy a 2014-ben és a 2018-ban megkérdezett adatközlők közel azonos eredményeket produkáltak, nemcsak a közölt példák esetén. A 2. ábra a 2018-as vizsgálat szerint a 3. csoportba tartozó szavakat sorolja fel: a sávok első fele a 2014-es, második, sötétebb fele a 2018-as százalékos adatokat mutatja. 


\section{2. táblázat}

Példák a legáltalánosabban használt és az alig használt tájszavak csoportjából: 2014-es ( $n=112)$ és 2018-as $(n=200)$ adatok százalékos eredményei alapján

\begin{tabular}{|c|c|c|}
\hline Tájszó & $\mathbf{2 0 1 4}$ & $\mathbf{2 0 1 8}$ \\
\hline \hline barátfüle & $48 \%$ & $54 \%$ \\
\hline kaccsa (szölönek) & $53 \%$ & $54 \%$ \\
\hline kánya & $60 \%$ & $61 \%$ \\
\hline réce & $57 \%$ & $60,5 \%$ \\
\hline sámli & $64 \%$ & $71,5 \%$ \\
\hline biling & $2,7 \%$ & $2,5 \%$ \\
\hline csemcseg & $3,7 \%$ & $5 \%$ \\
\hline pörc & $8 \%$ & $9,5 \%$ \\
\hline uritök & $8,9 \%$ & $3,5 \%$ \\
\hline zsurmol & $5,3 \%$ & $8 \%$ \\
\hline
\end{tabular}

A két vizsgálat eredményei közötti, a kategorizálás szempontjából releváns eltérések a következők voltak: 2014-ben a kusztora és a neveletlenujj szót egy-egy adatközlö jelölte használatosnak megfelelö magyarázat mellett, a hidas-t pedig két fö, míg 2018ban egy sem, a lajtergya/lajtorgya szót viszont akkor senki, az új vizsgálatban öt fö. A friss felmérés szerint egy fö ismerte és használta a pesszeg szót, két fö a dönög, a körmöz és a zömöcskös szavakat, négy fö a préshurká-t, míg 2014-ben senki. A zsugori és a barátfüle a 2014-es adatok alapján néhány fó válasza híján a 3. csoportba kerültek (112 főböl 50 fö $=45 \%$, illetve 54 fö $=48 \%$ ), míg a 2018-as adatok szerint a 4 . csoportba (200 föböl 107 fö $=53,5 \%$, illetve 108 fö $=54 \%$ ), a csettent a 2014-es adatok alapján a 2. csoportba (9 fó $=8 \%$ ), míg 2018-as adatok szerint a 3. csoportba (32 fö = 16\%). A 88 tájszóból csupán a 11 darabot érintő, nem számottevő különbség összességében elenyészőnek mondható. 


\section{2. ábra}

Az adatközlők legalább tizede, de kevesebb, mint a fele által használt és ismert tájszavak százalékos eredményei: 2014-es $(\mathrm{n}=112)$ és 2018-as $(\mathrm{n}=200)$ adatok

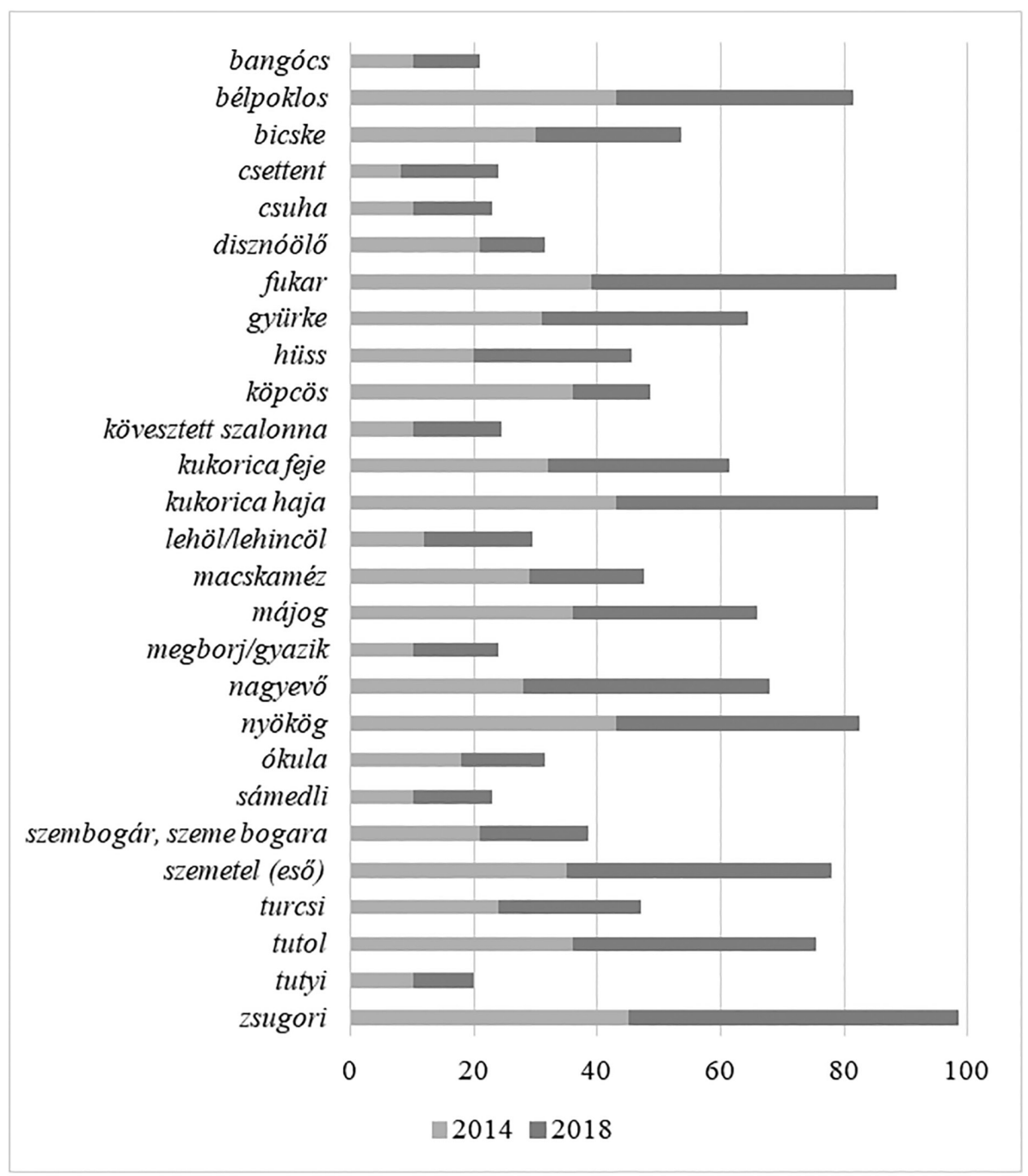

5. Következtetések. Az eredmények igazolták a feltevést, a 2014-ben és a 2018-ban végzett anyaggyüjtéssel is. A serdülökorú adatközlök közül többen számos környékbeli tájszót ismernek és használnak ugyanabban a jelentésben, amelyet a Nagyatlasz is közöl.

Összegezve a 2018 őszén végzett kutatás előző pontban közölt részleteit: Az egyáltalán nem használt szavak csoportjába a megkérdezett tájszavak 15,9\%-a került. A tájszavak 40,9\%-át csupán néhány adatközlö használja, 29,5\%-át pedig a vizsgált közösség legalább tizede, de kevesebb, mint a fele. A tájszavak 13,6\%-át a megkérdezettek nagyobb része használja. 
A legtöbb szót tartalmazó csoport a fenti összesítés alapján az, amelyeket az adatközlők kevesebb, mint a tizede használ tájnyelvi jelentésében. A harmadik és a negyedik csoport tagjainak az összeadásával azonban már azt mondhatjuk, hogy a legnagyobb arányban $(26+12=38 \mathrm{db}=43,2 \%)$ azok a szavak képviseltetik magukat a kutatásban, amelyeket a 200 föből legalább 20 fő (pl. bangócs, csuha, disznóölö, sámedli, tutyi), de akár 143 fö is használ (sámli), sőt figyelembe véve a birka és a csibe kiugróan magas adatait 173 fö, illetve 179 fö. Az adatok csoportosítgatása természetesen nem lehet szolgálólánya az igazolni kívánt hipotézisnek, miközben egyébként sincsenek pontos számbeli értékkategóriák a regionalitás felméréséhez. Azt azonban világosan és objektíven mutatják az eredmények, hogy a nyelvjárási jegyek a mai fiatalok nyelvhasználatában is megjelenhetnek.

Az a tény, hogy a különböző időben, különböző évfolyamok tagjainak - összesen 312 fönek - a részvételével zajlott vizsgálat eredményei teljes összhangban állnak egymással, arra enged következtetni, hogy a mintavétel megfelelő minőségü a vizsgált környezet és korosztály nyelvhasználatának adekvát leírásához, noha a teljes képhez érdemes volna felmérni a környék más középiskolái tanulóinak a tájszókészletét és további regionalizmusait is.

6. Kitekintés. Jelen tanulmány a 14-18 éves vidéki gimnazisták tájszókészletéröl közöl adatokat. Láthattuk viszont, hogy már az ehhez gyüjtött írásos anyagban is megjelennek adalékok a terület hangtani és alaktani jegyeinek a vizsgálatához (1. a 4. pontban).

E néhány és esetleges adaton kívül a korosztály tagjai körében a kutatás helyszínén eltöltött egy évtized nagy mennyiségben szolgáltatott számomra további, akár szóbeli, akár írásos adatokat részt vevő megfigyelés útján (az elsődleges és másodlagos írásbeliségből származó adatokhoz 1. PARAPATICS 2016a és 2020b). Noha e passzív gyüjtési módszer csupán véletlenszerű adatokat eredményez, megbízhatóságuk kétségtelen, hiszen a beszélők nem tudatosan, nem interjúhelyzetben, továbbá saját környezetükben, természetes, mindennapi kommunikációjuk során közölték. A formális regisztert legfeljebb az iskolai közeg hívja elő, ám a relatíve szoros, éveken át napi szinten fennálló kapcsolat tanár (a kutató személye) és diák között azt is inkább az informalitás irányába tereli, különösen azokban a megnyilatkozásokban, amelyek nem tanórai számonkérés során születnek, azokban az esetekben viszont az izgalom csökkenti a nyelvhasználatra fordított energiákat, az audiomonitoros folyamat müködését (vö. LABOV 1966), ami például köznyelvi variánsokat kereshetne a tájnyelviek helyére. Mindemellett érdemes volna rétegzett mintavétel és aktív gyüjtési módszerek útján nyert adatok elemzésével is felmérni a regionális hangtani és alaktani sajátosságok jelenlétét a (környékbeli) iskolások nyelvhasználatában, valamint a tanulók ezekhez füződő attitüdjeit és nyelvi-nyelvjárási tudatát. Fontos volna megfigyelni és más módszerekkel is igazolni a fiatalok tájszóhasználatára vonatkozó, jelen tanulmányban közölt eredményeket.

Számos további elemzési szempontot kínálnak a kérdőívek is. A tájszavakkal kapcsolatos kérdésekre adott válaszok részletesen vizsgálhatóvá teszik például azt, hogy mely szavakat használják az adatközlő családjának idősebb tagjai (is); míg a kérdőív végén megkérdezett személyes adatok révén további szociológiai változók építhetők be egy átfogó vizsgálatba. Korrelációs elemzések révén kiderülhet, milyen mértékben befolyásolja az adatközlők tájszóismeretét például lakóhelyük (az oktatás helyszínével megegyező kisváros vagy a környékbeli falvak egyike), a nagyszülőkkel való találkozás gyakorisága, a szülők elsődleges szocializációjának a helyszíne, illetve az, hogy a két szülő szociali- 
zációjának a helyszíne megegyezik-e nagyjából, vagy két különböző nyelvjárási régióból származva alkalmazkodtak-e egymás nyelvhasználatához. Érdemes volna összevetni az eredményeket az Új magyar nyelvjárási atlasz projekt keretében 2007 és 2012 között a környéken (pl. Kapolcs, Szentgál kutatóponton) gyüjtött adatokkal, különös tekintettel a fiatalabb adatközlőkre (vö. ÚMNyA.).

Összegzésképpen elmondható: a tanulmányban vizsgált és a további adalékokként nyert nyelvi információk egyrészt újabb bizonyítékot jelentenek arra, hogy a mai fiatal nemzedékek tagjainak nyelvhasználatában is nagy számban találhatók regionalizmusok, másrészt további tervezett és módszeres kutatások elvégzésére buzdítanak a témában.

7. Köszönetnyilvánítás. Köszönöm a tapolcai Batsányi János Gimnázium és Kollégium vezetésének és pedagógusainak, hogy megfelelő körülményeket biztosítottak számomra az anyaggyüjtéshez, valamint a tanulóknak komoly munkájukat és válaszaikat.

Kulcsszók: nyelvjárási háttér, regionalizmusok, fiatalok, nyelvatlasz, tájszó.

\section{Hivatkozott irodalom}

AMMON, VON UlRICH - KNOOP, UlRICH - RADTKE, INGULF Hrsg. 1978. Grundlagen einer dialektorientierten Sprachdidaktik. Theoretische und empirische Beiträge zu einem vernachlässigten Schulproblem. Beltz, Weinheim-Basel.

Ammon, Ulrich - MATtheIER, Klaus J. - Nelde, Peter H. Hrsg. 1989. Sociolinguistica 3. Internationales Jahrbuch für Europäische Soziolinguistik. Dialekt und Schule in den europäischen Ländern. Max Niemeyer, Tübingen.

BODÓ CSANÁD - FAZAKAS NOÉMI 2018. Enregistering authenticity in language revitalisation. Journal of Sociolinguistics 22/5: 570-594.

BODA ANNAMÁRIA 2011. A helyesírás tanítása nyelvjárási hátterü tanulók számára. Anyanyelv-pedagógia 3. URL: http://www.anyp.hu/cikkek.php?id=333 (2019. 03. 07.)

BOROS ILDIKÓ 2010. Mit tudnak a veszprémi nyolcadikosok a nyelvjárásokról? In: HÁRI GYULA H. TÓTH TiвOR szerk., Regionalitás és nyelvjárásiasság Veszprém megyében. Pannon Egyetem Magyar Nyelvtudományi Tanszék, Veszprém. 59-63.

Czetter Ibolya - Hajba RenÁta - Tóth PÉTER szerk. 2016. VI. Dialektológiai Szimpozion: Szombathely, 2015. szeptember 2-4. Nyugat-Magyarországi Egyetem Savaria Egyetemi Központ Nyitrai Konstantin Filozófus Egyetem Közép-európai Tanulmányok Kara, Szombathely-Nyitra.

FodOR KATALIN 2003. Csehországtól Szibériáig. Avagy mennyit tudnak az egyetemi hallgatók a csángókról. In: HAJdÚ MiHÁLY - KESZLER BorBÁlA szerk., Köszöntö könyv Kiss Jenö 60. születésnapjára. ELTE Magyar Nyelvtudományi és Finnugor Intézet, Magyar Nyelvtudományi Társaság, Budapest. 285-289.

GutTMANN MiKLÓS 1995. A táji jelenségek vizsgálata tiz- és tizennégy évesek beszélt nyelvében Nyugat-Dunántúlon. A Magyar Nyelvtudományi Társaság Kiadványai 202. Magyar Nyelvtudományi Társaság, Budapest.

GutTMANN MiKLÓS 1999. Az iskola és a regionális nyelviség. In: V. RAISZ RózSA - H. VARGA GYULA szerk., Nyelvi és kommunikációs kultúra az iskolában. A Magyar Nyelvtudományi Társaság Kiadványai 212. Magyar Nyelvtudományi Társaság, Budapest. 421-427.

HajBA RenÁta 2012. Regionális nyelvhasználat Szombathelyen. Doktori disszertáció. Kézirat. ELTE Nyelvtudományi Doktori Iskola, Budapest. 
HANICZKO ANNA 2017. Nyelvjárási jelenségek hatása általános iskolás tanulók írásgyakorlatára Tornalján. Magyar Nyelv 113: 479-484.

HegedŰs AtTila 2005. A változó nyelvjárás. Pázmány Péter Katolikus Egyetem Bölcsészettudományi Kar, Piliscsaba.

HELTAINÉ NAGY ERZSÉBET 2004. Dialektológiai és szociolingvisztikai tanulságok a nyelvművelés számára. In: P. LAKATOS ILONA - T. KÁROLYI MARGIT szerk., Nyelvvesztés, nyelvjárásvesztés, nyelvcsere. Tinta Könyvkiadó, Budapest. 101-107.

HondA, MAYA - O’NEIL, WAYNE - PIPPIN, DAVID 2010. On promoting linguistics literacy: Bringing language science to English classroom. In: DENHAM, KRISTIN - LOBECK, ANNE eds., Linguistics at School. Language Awareness in Primary and Secondary Education. Cambridge University Press. Cambridge. 175-188.

HUDSON, RICHARD 2004. Why education needs linguistics (and vice versa)? Journal of Linguistics 40/1: 105-130.

Husby, Olaf ed., Høyte, Tore - Nefzaoui, Sissel Jensen - Nordli, Ingrid C. - Robbins, Sissel - ØVRegaARD, Åsta 2008. An introduction to Norwegian dialects. Tapi Academic Press, Trondheim.

JÁNK ISTVÁN 2018. Nyelvi diszkrimináció és nyelvi elöitéletesség a pedagógiai értékelésben. Doktori disszertáció. Kézirat. Nyitrai Konstantin Filozófus Egyetem, Nyitra.

JuHÁsz DEZSŐ 2001. A magyar nyelvjárások területi egységei. In: MDial. 262-316.

JUHÁSZ DEZSŐ 2002. Magyar nyelvjárástörténet és történeti szociolingvisztika: tudományszemléleti kérdések. In: HofFMANN ISTVÁN - JuHÁsz DEZSÖ - PÉNTEK JÁNOS szerk., Hungarológia és dimenzionális nyelvszemlélet. Elöadások az V. Nemzetközi Hungarológiai Kongresszuson (Jyväskylä, 2001. augusztus 6-10.). Debreceni Egyetem - Jyväskyläi Egyetem, DebrecenJyväskylä. 165-173.

KISS JENÖ 1998. Helyes és helytelen (nyelvjárási környezetü általános iskolások nyelvi adatainak tükrében). Magyar Nyelv 94: 257-269.

KISS JENŐ 2000. Magyar nyelvjárástani kalauz. Eötvös Loránd Tudományegyetem, Bölcsészettudományi Kar, Mai Magyar Nyelvi Tanszék, Budapest.

KISS JENŐ 2009. A nyelvjárások és a dialektológiaoktatás Kárpát-medencei magyar szakos hallgatók szemével. Magyar Nyelvör 133: 1-14.

KISS JENŐ 2010. Anyanyelvi órák a középiskolában: egy fölmérés tanulságaiból. Magyartanitás 51: 24-25.

KISS JENŐ 2013. A regionális nyelvhasználat és a nyelvi kontaktusok. Problémavázlat. In: AGYAGÁSI KLÁRA - HEGEDÜS ATTILA - É. KISS KATALIN szerk., Nyelvelmélet és kontaktológia 2. PPKE BTK Elméleti Nyelvészeti Tanszék - Magyar Nyelvészeti Tanszék, Piliscsaba. 80-94.

KISS JENŐ 2015. A magyar dialektológiáról tudományszociológiai megközelítésben. Magyar Nyelv 111: 385-394.

KISS JENŐ 2017. A nyelvjárások. In: TOLCSVAI NAGY GÁBOR szerk., A magyar nyelv jelene és jövője. Gondolat Kiadó, Budapest. 199-221.

KONTRA MiKLós 2006. A magyar lingvicizmus és ami körülveszi. In: BAKRÓ-NAGY MARIANNE SIPŐCZ KATALIN - SZEVERÉNYI SÁNDOR szerk., Elmélkedések nyelvekröl, népekröl és a profán medvéröl. Írások Bakró-Nagy Marianne tiszteletére. Szegedi Tudományegyetem Finnugor Nyelvtudományi Tanszék, Szeged. 83-106.

Kontra MiKLós - NÉMETH MiKLÓs - SinKovics BALÁzs 2016. Szeged nyelve a 21. század elején. Gondolat Kiadó, Budapest.

Koós ILDIKÓ 2017. A nyelvjárási regiszter használatával összefüggésbe hozható helyesírási hibák elemzése nyugat-dunántúli általános iskolások írásmunkái alapján. Képzés és Gyakorlat 15/4: $115-124$. 
KT = A kerettantervek kiadásának és jóváhagyásának rendjéről szóló 51/2012. (XII. 21.) számú EMMI rendelet mellékletei. http://kerettanterv.ofi.hu (2019. 01. 08.)

Labov, William 1966. The Social Stratification of English in New York City. Center for Applied Linguistics, Washington D. C.

LÖFFLER, HeINRICH 1985. Germanistiche Soziolinguistik. Erich Schmidt Verlag, Berlin.

MDial. = KISS JENŐ szerk., Magyar dialektológia. Osiris Kiadó, Budapest.

MNyA. = A magyar nyelvjárások atlasza 1-6. Szerk. DEME LÁszLó - IMrE SAMU. Akadémiai Kiadó, Budapest, 1968-1977.

CS. NAGY LAJOS - N. CSÁSZI ILDIKÓ 2015. Magyar nyelvjárások. Tinta Könyvkiadó, Budapest.

NAT $=$ Nemzeti Alaptanterv. 110/2012 (VI. 4.) Korm. rendelet. Magyar Közlöny 66. szám. 2012. június 4.: 10635-10847.

NÉMETH MiKLÓs 2006. Hegedűs Attila 2005: A változó nyelvjárás. Nyelvtudomány 2: 255-261.

PARAPATICS ANDREA 2016a. A nyelvjárások írásbeliségéröl fiatalok nyelvhasználatában. In: KÁROLY KRISZTINA - HOMONNAY ZOLTÁN szerk., Kutatások és jó gyakorlatok a tanárképzés tudós mühelyéböl. ELTE Eötvös Kiadó, Budapest. 94-109.

PARAPATICS ANDREA 2016b. Tények és tapasztalatok a dialektológiai ismeretek tanításáról. In: CzETTER IBOLYA - HAJBA RENÁTA - TÓTH PÉTER szerk., VI. Dialektológiai Szimpozion: Szombathely, 2015. szeptember 2-4. Nyugat-Magyarországi Egyetem Savaria Egyetemi Központ - Nyitrai Konstantin Filozófus Egyetem Közép-európai Tanulmányok Kara, Szombathely-Nyitra. 509-517.

PARAPATICS ANDREA 2018. Nyelvjárástani munkafüzet. Tinta Könyvkiadó, Budapest.

PARAPATICS ANDREA 2020a. A magyar nyelv regionalitása és a köznevelés. Tények, problémák, javaslatok. Tinta Könyvkiadó, Budapest.

PARAPATICS ANDREA 2020b. Regionális nyelvi sajátosságok megjelenése és megítélése a közösségi médiában. Médiakutató XXI/2: 59-73.

PÉNTEK JÁNOS 2015. Péntek János üdvözlő szavai. In: JUHÁSZ DEZső szerk., Kérdések és válaszok a nyelvtudományban. Jelen, múlt, jövő. Válogatás Kiss Jenő tanulmányaiból 1-2. ELTE Eötvös Kiadó, Budapest. 1: 15-18.

PLETL RITA 1997. Erdélyi helyzetkép az iskolai helyesírásról. Infopress, Székelyudvarhely.

STRELI ZITA 2007. A székesfehérvári székelyek és a szlavóniai csángók - avagy mit tudnak a középiskolások a nyelvjárásokról. In: GUTTMANN MikLÓs - MolNÁr ZolTÁN szerk., V. Dialektológiai Szimpozion. Szombathely, 2007. augusztus 22-24. Berzsenyi Dániel Föiskola BTK Magyar Nyelvészeti Tanszék, Szombathely. 244-251.

SZENTGYÖRGYI RUDOLF 2015. Anyanyelvünk változatai. In: ANTALNÉ SZABÓ ÁGNES - RAÁTZ JUDIT VESZELSZKI ÁGNES szerk., Mozaikok a magyar nyelvröl és a nyelvhasználatról. Segédkönyv az anyanyelvi kritériumvizsgához. Eötvös Loránd Tudományegyetem, Budapest. 143-161.

ÚMNyA. = [Új magyar nyelvjárási atlasz.] Az MTA-ELTE Geolingvisztikai Kutatócsoport honlapja. http://umnya.elte.hu (2019. 03. 07.)

ÚMTsz. = Új magyar tájszótár 1-5. Főszerk. B. LÖRINCZY ÉVA. Akadémiai Kiadó, Budapest, 19792010.

VAngsnes, Øystein A. - Söderlund, Göran B. W. - BleKesaune, Morten 2017. The effect of bidialectal literacy on school achievement. International Journal of Bilingual Education and Bilingualism 20/3: 346-361.

\section{On the dialect word stock of youngsters in the Balaton region in the light of a survey study}

The paper presents the results of a dialect word stock study that was conducted in 2018 among 14-18-year-old students of a secondary grammar school in the Middle Transdanubian dialect region. 
The respondents $(n=200)$ live in the small town where they attend school or in the neighboring villages. They filled a questionnaire of 88 dialect words that had been attested at the closest research points (Diszel, Kapolcs, Szentgál) of the Dialect Atlas of Hungarian and have a chance to be known among young speakers of today. 14 dialect words of the questionnaire were not used - and were not even known except one. 74 dialect words are used and 12 of them are used by more than half of the respondents. The study yielded nearly the same results as a former study of 2014 at the same school with the same methods. The author's hypothesis was confirmed: many young speakers know and use dialect words with the same denotata that can be found in the Dialect Atlas of Hungarian (the enormous amount of data of the atlas were collected between 1949 and 1964).

Keywords: dialect background, regionalisms, youngsters, dialect atlas, dialect word.

PARAPATICS ANDREA Pannon Egyetem

\section{T UDOMÁNYTÖRTÉNET}

\section{5 éve született Bárczi Géza*}

1. Bevezetés. Ennek az emlékezésnek az elsődleges célja az, hogy eleven képet fessen Bárczi Gézáról. Magam közelről ismerhettem őt: tanítását sok éven át hallgattam, s alkalmam volt személyiségének vonásait, sőt varázsát a közös munka során mind több oldalról felfedezni. Tanítványa voltam és vagyok, s ez életre szóló élményt jelent számomra. Ö maga immár 45 éve nincs közöttünk; az idő múlásával egyre kevesebben vagyunk, akik közvetíthetjük emlékét. Épp ezért személyes feladatunk e nagy tudós életművének és emberi alakjának a felidézése - amire a mostani évforduló kedvező lehetőséget kínál. A korábbi hasonló alkalmak emlékét számos köszöntő vagy megemlékező írás őrzi; ezekből itt-ott idézek majd. Elöre is kiemelném a közeli tanítvány, SZATHMÁRI ISTVÁN könyvét (1995), mely az életmü egészéröl átfogó képet ad.

2. Életútjának fó állomásai. Bárczi Géza Zomborban született 1894. január 9-én. Iskoláit is itt végezte. Korán elkezdett törökül tanulni: az volt a terve, hogy turkológus lesz. Megtanult eszperantóul; ezt a nyelvet gimnazistaként tanította is. Egy időben arra gondolt, hogy botanikus lesz. Ráismerhetünk ebben arra a színes érdeklődésre, amellyel általában a környező világ és az élet felé fordult, gyönyörködve annak különféle megnyilvánulásaiban. Bácskai gyerekkorára nézve tett egyszer egy emlékezetes, nyelvészeti érdekű megjegyzést: ő még hallott öreg papokat így misézni: [dominus vobiskum]. Történeti adalék ez az előző századforduló $s$-ező ejtésére a magyarországi egyházi latin nyelvben.

A budapesti e gyete men és az Eötvös Collegiumban végezte tanulmányait 1911-től, magyar-latin-görög szakon. A harmadév befejezése után, 1914 nyarán a Colle-

* Elhangzott 2019. november 19-én a Magyar Nyelvtudományi Társaság felolvasó ülésén.

DOI: 10.18349/MagyarNyelv.2020.3.351 